\title{
Knowledge-intensive business services: does dual embeddedness matter?
}

\author{
Zhaleh Najafi-Tavani • Axèle Giroud • Rudolf R. Sinkovics
}

\section{This is a pre-print (non-publisher's document). Please cite the published article:}

Najafi-Tavani, Zhaleh, Axèle Giroud, and Rudolf R. Sinkovics (2012), "Knowledge-intensive business services: Does dual embeddedness matter?," The Service Industries Journal, 32 (10), 1691-1705. (DOI: 10.1080/02642069.2012.665895). http://dx.doi.org/10.1080/02642069.2012.665895

\section{Abstract}

- Building on network theory, this study investigates knowledge development in subsidiaries in the knowledge-intensive business service (KIBS) sector. Foreign subsidiaries' internal and external networks are divided into three main categories: relations with (1) the local environment (external embeddedness), (2) parent firms (subsidiary-parent firm embeddedness and autonomy), and (3) sister subsidiaries (subsidiary-subsidiary embeddedness).

- Hypotheses are tested using a sample of 184 subsidiaries, located in the UK, whose parent firms are based outside the UK. While our results indicate that external embeddedness, subsidiary-parent embeddedness, and autonomy are main determinants of knowledge development within KIBS multinational companies, they show no association between subsidiary-subsidiary embeddedness and knowledge development.

\section{Key Words}

KIBS sector, knowledge development, embeddedness, MNCs

\section{Authors}

\author{
Zhaleh Najafi-Tavani $(\bowtie)$ \\ Lecturer in Marketing \\ Department of Marketing \\ Leeds University Business School, UK \\ (e-mail: z.najafitavani@leeds.ac.uk)
}

\section{Axèle L. Giroud}

Reader in International Business

Centre for Comparative \& International Business Research (CIBER) 
The University of Manchester, Manchester Business School

Booth Street West, Manchester M15 6PB, UK.

(e-mail: Axele.Giroud@mbs.ac.uk, Web: http://www.personal.mbs.ac.uk/agiroud )

Rudolf R. Sinkovics

Professor of International Business

Centre for Comparative \& International Business Research (CIBER)

The University of Manchester, Manchester Business School

Booth Street West, Manchester M15 6PB, UK.

(e-mail: Rudolf.Sinkovics@manchester.ac.uk, Web:

http://www.personal.mbs.ac.uk/rsinkovics ) 


\title{
Knowledge-Intensive Business Services:
}

\section{Does Dual Embeddedness Matter?}

\author{
Zhaleh Najafi-Tavani ${ }^{\mathrm{a}}$, Axèle Giroud ${ }^{\mathrm{b}}$ and Rudolf R. Sinkovics ${ }^{\mathrm{b}}$ \\ ${ }^{a}$ Department of Marketing, Leeds University Business School, Leeds, UK \\ ${ }^{\mathrm{b}}$ Manchester Business School, University of Manchester, Manchester, UK
}

(Received 14 April 2011; submitted in revised form: 29 September 2011; final version received 14

November 2011)

Building on network theory, this study investigates knowledge development in subsidiaries in the Knowledge-Intensive Business Service (KIBS) sector. Foreign subsidiaries' internal and external networks are divided into three main categories: relations with (a) the local environment (external embeddedness), (b) parent firms (subsidiary-parent firm embeddedness and autonomy), and (c) sister subsidiaries (subsidiary-subsidiary embeddedness). Hypotheses are tested using a sample of 184 subsidiaries, located in the United Kingdom, whose parent firms are based outside the UK. While our results indicate that external embeddedness, subsidiary-parent embeddedness and autonomy are main determinants of knowledge development within KIBS multinational companies, they show no association between subsidiary-subsidiary embeddedness and knowledge development.

Keywords: Knowledge-Intensive Business Service (KIBS) sector; knowledge development; embeddedness; Multinational Corporations (MNCs)

\section{Introduction}

Although Knowledge-Intensive Business Services (KIBS) is among the fastest-growing sectors in most developed countries (Koch \& Strotmann, 2008), there has been a surprising lack of studies of such companies in the international business literature. This might be due to 
the fact that it was traditionally assumed that manufacturing companies were the only entities capable of developing new knowledge (Windrum \& Tomlinson, 1999). Consequently, service companies were at best considered the users of new ideas and knowledge produced by their manufacturing counterparts. However, results of contemporary studies on the KIBS sector contradict the traditional view (den Hertog, 2000; Miles, Kastrinos, \& Flanagan, 1995; Muller, 2001). It has been argued that KIBS companies are 'bridges for innovation' between manufacturing and science (Czarnitzki \& Spielkamp, 2003).

In the literature on the KIBS sector, there are some studies focusing on factors that influence the ability of KIBS companies to develop new knowledge (Bettencourt, Ostrom, Brown, \& Roundtree, 2002; Muller, 2001). However, our knowledge of this phenomenon is limited. Firstly, few studies focus on KIBS firms operating internationally (Windrum \& Tomlinson, 1999). Therefore, to explain variations in firms' abilities to develop knowledge, these studies only include the impacts of local actors (customers, competitors, suppliers, etc.) in their analysis. However, it has been noted that subsidiaries are dually embedded in their internal and external environments (Frost, 1990, 2001). Consequently, while linkages with the internal units (parent firms and sister subsidiaries) might not be as influential as those with local actors, they can still serve as sources of competitive advantages for subsidiaries, and thus their effects on knowledge development should be considered.

Secondly, the international business literature has mainly focused on the manufacturing sector. However, there exist fundamental differences across the manufacturing and service industries. For example, unlike the manufacturing sector, patents are seldom used as a means of knowledge protection or knowledge transfer in the service industry (except in the case of software companies) (Doloreux, Amara, \& Landry, 2008; Grosse, 1996). Moreover, results of earlier studies on the manufacturing sector indicate that the existence of close relations between a subsidiary and its parent firm is a key component of knowledge development in the 


\section{Z. Najafi-Tavani et al.}

subsidiary. However, given that the nature of activities of service companies is substantially different (for instance, their activities are subject to greater demands of adaptation and localization), it remains unclear whether the knowledge base of the parent firm constitutes a key requirement for knowledge development in subsidiaries in services.

Building on the network view of the firm, our study contributes to the current debate by linking two streams of literature: one focusing on (a) knowledge development within the KIBS sector, and one focusing on (b) international knowledge development. In line with Kogut and Zander (1992), knowledge development is defined as the recombination of existing knowledge by a firm. We utilize the business network concept of relationship-specific knowledge, i.e. knowledge developed by foreign subsidiaries through interaction with internal and external actors (Forsgren, Holm, \& Johanson, 2006; Johanson \& Vahlne, 2009), as studies have shown that subsidiaries that have the ability to access and absorb knowledge do so from both the MNC and host-country networks (Almeida \& Phene, 2004), and subsidiaries need both host-market knowledge and internal relationships to enhance their strategic significance within the MNC network (Bouquet \& Birkinshaw, 2008).

For the reasons mentioned above, the impacts of a subsidiary's relations (with (a) its parent firm, (b) sister subsidiaries, and (c) local actors) on knowledge development are empirically investigated. The joint inclusion of the subsidiary's relations with its internal and external actors simultaneously enables us to identify the main source of subsidiary knowledge

development. Four hypotheses are developed and address the relationship between a subsidiary's internal and external relations and extent of knowledge development. These hypotheses are tested employing a sample of 184 subsidiaries operating in the UK KIBS sector.

The paper is organized as follows. We first discuss the theoretical background, followed by hypothesis development, wherein we investigate the impacts of subsidiaries' relations (with 
local environment, parent firms and sister subsidiaries) on knowledge development. Details of data collection, measures, data analysis and results are then presented. In the final section, we discuss the results and managerial implications.

\section{Knowledge-intensive business services and knowledge development}

KIBS firms are mainly small to medium-sized enterprises or recently founded firms, and many are established as a result of outsourcing or 'spin-off processes' (Koch \& Strotmann, 2008). Following Miles et al., we define the knowledge-intensive services as 'services that involve economic activities which are intended to result in the creation, accumulation or dissemination of knowledge' (Miles, et al., 1995, p.18). Such services are usually found within 'expertise' or 'information rich' companies (Muller \& Doloreux, 2009). According to Johannisson (1998), tacit knowledge plays a pivotal role in the KIBS sector. Authors have suggested that, to acquire and develop tacit knowledge, KIBS firms should have close and frequent relations with local actors and, in particular, customers (Bettencourt, et al., 2002; den Hertog, 2000; Muller \& Zenker, 2001). Customers of KIBS companies are even considered to be 'co-producers' and 'co-creators' of new knowledge (den Hertog, 2000). The findings of other studies also point to the critical role of customers, suppliers, competitors, universities and other research institutes in the success of knowledge development activities in the KIBS sector (Czarnitzki \& Spielkamp, 2003; Doloreux, et al., 2008).

Foreign subsidiaries benefit from additional sources of knowledge, as compared with domestic KIBS companies, since access to knowledge is not limited to the local environment. It has been shown that subsidiaries are simultaneously linked to their internal and local networks (Frost, 2001; Yamin, 1999), and as such, they can potentially benefit from both. Not all subsidiaries will benefit from the same access to knowledge, and we argue that the extent to which they can benefit from internal knowledge networks depends heavily on the characteristics of their relationships with other MNCs units (Uzzi, 1997). Relationships have 


\section{Z. Najafi-Tavani et al.}

been conceptualized in various ways in earlier studies; namely, they have been referred to as the degree of internal and local embeddedness (Andersson, Björkman, \& Forsgren, 2005; Håkanson \& Nobel, 2001), intensity of interactions (Nobel \& Birkinshaw, 1998) and level of autonomy (Birkinshaw \& Hood, 1998; Grevesen \& Damanpour, 2007). Following Andersson et al. (2005) and Andersson, Forsgren \& Holm (2001), we use the concept of embeddedness when defining attributes of a subsidiary's relationships. Thus, subsidiaries' relations can be divided into three groups: relations with the parent firm, relations with sister subsidiaries, and relations with local actors. Embeddedness represents a powerful knowledge-gathering device, which, in turn, can boost a subsidiary's ability to develop knowledge (Rogers \& Larsen, 1984). Other studies have suggested that the level of a subsidiary's autonomy also influences relationships between a subsidiary and its parent (Birkinshaw, Hood, \& Jonsson, 1998; Ghoshal \& Bartlett, 1988). Autonomy has been shown to positively influence knowledge development capability in the manufacturing sector (Birkinshaw \& Hood, 1998; Grevesen \& Damanpour, 2007; Mudambi, Mudambi, \& Navarra, 2007), but to our knowledge, this influence has not been demonstrated in the case of KIBS firms. There is reason to believe, however, that level of autonomy would play a significant role for these firms, given the ability of the foreign subsidiary to develop its local relationships with higher levels of autonomy. In this paper, we therefore investigate the impact of subsidiary autonomy and relationship characteristics on knowledge development.

\section{External embeddedness}

The extant literature draws attention to the way embedded relations impact upon the ability of firms to develop new knowledge (Taggart, 1997; Teece, 1977). On the one hand, close relations can negatively impact firms' knowledge development by restricting their ability to bridge disconnected networks, and thus restrict accessibility to novel ideas (Taggart, 1997). On the other hand, it has been argued that the importance of embedded relations varies 
depending on the nature of knowledge (Teece, 1977). More specifically, when the knowledge is highly complex and tacit, the more embedded firms are within their local environment, the better they are able to identify and absorb such knowledge.

Knowledge-intensive companies operate in an environment characterized by high levels of uncertainty and instability, because of fast changes occurring in the competitive landscape (Williams \& Nones, 2009). As a result, although the knowledge residing in the local environment is a core competitive advantage of foreign subsidiaries, absorbing such knowledge is not an easy task. Unlike information, market knowledge is highly tacit and context-specific (Roth, Jayachandran, Dakhli, \& Colton, 2009); thus, it should be acquired through social and professional interactions (Porter, 1990). In other words, the more integrated subsidiaries are in their local environment, the easier they can acquire this contextspecific knowledge (Andersson, et al., 2005; Sternberg \& Arndt, 2001). Studies conducted on firms in the manufacturing sector find that external embeddedness facilitates the ability of the firm to develop knowledge (Birkinshaw, 1996; Håkanson \& Nobel, 2001; Kotabe, Martin, \& Domoto, 2003). For instance, technological reliance on local actors is a key source of a subsidiary's competitiveness (Birkinshaw, 1996; Kotabe, et al., 2003). As a result, we suggest that close external relations promote firms' knowledge development; firstly, because maintaining close external relations reduces the risks and costs associated with the exchange of resources; secondly, because these relations increase accessibility of knowledge; and thirdly, because they enhance learning processes (Muller \& Zenker, 2001). Hence, the following hypothesis is formulated:

Hypothesis 1. The more embedded the relationships between a subsidiary and its local actors, the more the subsidiary is capable of developing new knowledge.

\section{Subsidiary-parent firm embeddedness}




\section{Z. Najafi-Tavani et al.}

The literature on subsidiary knowledge development highlights the importance of subsidiaryparent firm relationships as a fundamental determinant of knowledge development (Birkinshaw, et al., 1998; Gupta \& Govindarajan, 1991). Birkinshaw et al., for instance, demonstrate that the frequency of subsidiary-parent firm communication (as an indication of relationship attribute) is significantly associated with the subsidiary's ability to develop knowledge. Ghoshal and Bartlett (1988) identify normative integration and shared values as one of the main determinants of a subsidiary's ability to develop knowledge.

Compared to domestic firms, foreign subsidiaries benefit from the added advantage of having access to the MNC's knowledge resources. It has been shown that the ability of subsidiaries to develop knowledge depends to a large extent on accessing various internal sources of knowledge (Frost, 1990, 2001). Given the specific nature of the KIBS sector, the exchange of knowledge can be very difficult and resource-consuming for both parent firms and subsidiaries. The underlying idea is that tacitness impedes knowledge exchange activities, through negatively influencing the subsidiary's learning abilities. In such circumstances, knowledge can be transferred efficiently only through embedded relationships between sender and receiver (Hansen, 2002). In fact, these close relations can be considered as a stock of knowledge in which knowledge is accumulated and dispersed over time (Szulanski, 1996).

We therefore suggest that:

Hypothesis 2. The more embedded the relationships between a subsidiary and its parent firm, the more the subsidiary is capable of developing new knowledge.

\section{Autonomy}

Autonomy is usually defined as the extent to which subsidiaries are allowed to make decisions about their most strategically important activities or issues. The traditional view on knowledge flow within MNCs was that the lower the level of autonomy, the higher the knowledge flows between the subsidiary and its parent, following the assumption that the 
probability of transferring relevant knowledge is higher for inter-dependent units (Egelhoff, 1988). Recent contributions, however, suggest otherwise. For instance, Gupta and Govindarajan (1991) suggest that the level of autonomy should be high for Global Innovators (subsidiaries highly involved in knowledge development activities), but low for Implementers (subsidiaries rarely developing new knowledge).

Organizational studies agree, in general, that the level of autonomy can significantly, and positively, affect a firm's ability to develop new knowledge (Birkinshaw \& Hood, 1998; Cantwell \& Piscitello, 1999; Nobel \& Birkinshaw, 1998). For example, according to Cantwell and Piscitello (1999), a higher level of autonomy positively influences subsidiary knowledge development, since it allows a subsidiary to make decisions quickly and independently. Frost, Birkinshaw \& Ensign (2002) found that autonomous subsidiaries are highly capable of developing knowledge, since they can freely recognize and pursue local opportunities. Other studies support a link between autonomy and the development of centres of excellence (Frost, et al., 2002).

In contrast, a high level of centralization influences knowledge development negatively by diminishing the level of risk-taking and openness to new ideas (Grevesen \& Damanpour, 2007; Miller, Droge, \& Toulouse, 1988). Ghoshal and Bartlett (1988) argue that a low level of autonomy hinders subsidiary knowledge development by limiting the freedom to experience. To be innovative, KIBS firms not only need to be integrated into their local environment, but should also be capable of learning (Miles, et al., 1995). A low level of autonomy could thus negatively affect a subsidiary's ability to develop knowledge by impacting negatively on learning patterns (Damanpour, 1991; Miller, et al., 1988) and by limiting external embeddedness in the local environment . As a result, we suggest:

Hypothesis 3. The greater the level of autonomy of a subsidiary, the more the subsidiary is capable of developing new knowledge. 


\section{Z. Najafi-Tavani et al.}

\section{Subsidiary-subsidiary embeddedness}

Within the network view, a foreign subsidiary benefits not only from its relationships within the host external environment and with its parent firm, but it can also benefit from knowledge existing in other units of the firm (including sister subsidiaries). It has been shown that the quality of knowledge development in MNCs can be improved by transferring and recombining knowledge originating from a dispersed network of firms (Zander \& Sölvell, 2000). Sister subsidiaries have access to various markets and 'technological specialisation' (Almeida \& Phene, 2004), and, according to Hoang and Rothaermel (2010), they possess knowledge the focal subsidiaries lack, and it is the use of such knowledge that facilitates new knowledge development.

As indicated earlier, the main function of KIBS firms is to develop new knowledge (Muller \& Zenker, 2001), and their competitive advantage relies on absorbing and diffusing knowledge (Bettencourt, et al., 2002); yet knowledge residing in this sector is highly tacit in nature and embedded in employees' experiences and skills (Doloreux, et al., 2008; Grosse, 1996). The literature suggests that highly tacit knowledge is best transferred through embedded relationships (Ghoshal \& Nohria, 1989; Windrum \& Tomlinson, 1999). Zander and Solvell (2000) further suggest that the existence of close relations is key for managing geographically diversified R\&D and knowledge development activities. Close relations not only promote reciprocal collaboration and create trust, they also ease knowledge-sharing activities (Schreiner, Kale, \& Corsten, 2009), decrease opportunistic behaviours, minimize misuse of knowledge, and, therefore, enhance openness of the knowledge holder (Squire, Cousins, \& Brown, 2009). This explains why inter-personal relations are crucial for crossborder knowledge transfer in the case of service firms (Buckley, Pass, \& Prescott, 1992), thereby facilitating knowledge development. Thus, we suggest: 
Hypothesis 4. The more embedded the relationships between a subsidiary and its sister subsidiaries, the more the subsidiary is capable of developing new knowledge.

\section{Data and method}

\section{Data Collection}

The formulated hypotheses are tested using data on subsidiaries located in the UK, active in the KIBS sector. Using Simmie and Strambach's (2006) classification, the survey was conducted amongst 'computer services', 'research and development', 'economic services', 'technical services' and 'advertising' companies, as these sub-sectors qualify as being the most knowledge-intensive.

The survey was designed and implemented following Dillman's (2000) tailored design method. To check the face validity, the survey was first pre-tested by fifteen PhD students, selected academics and 50 KIBS companies. The list of companies was drawn from the FAME database (which provides company information for UK public and private companies). Data was collected in early 2009, by means of an online survey. 523 top managers of subsidiaries (CEOs, general managers, managing directors) were contacted by phone. A personalized covering letter containing the link to the survey was then emailed to them. Two follow-ups were conducted. The final response rate was 39\%. In total, 209 responses were collected, though not all useable. The sample used in this paper consists of 184 companies. The age and size of subsidiaries in the sample range from 10 to 55,000 employees (with an average of 5,000) and from 1 to 60 years old (with a mean of 15). Parent firms are mainly located in Europe (43\%) or North America (40\%), with a few in Asia, Australia, South America or Africa.

We tested non-response bias by comparing non-respondents with respondents, based on age, location of parent firm, and number of employees (Gerbing \& Anderson, 1988). The ttest indicates no significant differences across the groups. In addition, we compared answers 


\section{Z. Najafi-Tavani et al.}

provided by early and late respondents, in terms of knowledge development and the extent of external embeddedness. As no significant differences were found, we conclude that neither late response nor non-response bias represent a major problem in our research. To minimize the possibility of common method variance (CMV), some precautions (such as providing explanations for ambiguous terms and ensuring anonymity) were taken. However, since the data were all collected through the same survey instrument, some concerns could remain. Harman's one-factor test was used to check the possibility of CMV (Konrad \& Linnehan, 1995). The results of the principal components factor analysis yielded five factors with eigenvalues greater than 1.0 , which accounted for $76.61 \%$ of the variance, with the first factor accounting for $29.79 \%$. Therefore, we conclude that CMV is not a problem in this research (Podsakoff \& Organ, 1986). To further control for CMV, we collected objective data on the age of 30 subsidiaries in the sample, combining data extracted from the FAME database and from individual companies' websites. Theory suggests that the older the subsidiary, the higher the degree of external embeddedness (Forsgren, et al., 2006; Håkanson \& Nobel, 2001; Uzzi, 1997). The correlation between objective age data and (a) subsidiary-parent firm embeddedness and (b) external embeddedness were $0.61 \quad(\mathrm{p}<0.01)$ and $0.64 \quad(\mathrm{p}<0.01)$ respectively, confirming that CMV is not a concern.

\section{Measures}

\section{Knowledge development}

The measurements used for knowledge development were adapted from Andersson et al. (2005). This research focuses on the development of the following types of knowledge: sales and marketing know-how, distribution know-how, service production strategy know-how and management systems and practices know-how. On a seven-item scale, ranging from 1 'not at all' to 7 'to a very great extent', the respondents were asked to answer the following question: 
'To what extent during the last three years did your company develop ... knowledge which is superior to that of your headquarters, sister companies or competitors?'

\section{External embeddedness}

External embeddedness is related to existing relationships between a firm and its most important local actors, and how these relationships result in the mutual adaptation of activities. In this research, universities and research institutes, customers and suppliers are considered as external or local actors. On a seven-point scale (from 1 'not at all' to 7 'to a very great extent'), respondents were asked to indicate 'the extent to which the subsidiary's most important external relationships with customers, suppliers, universities and research institutes have caused mutual adaptation concerning a) sales and marketing practices, b) distribution practices and c) management system and practices'. The measures were developed from the contributions of Lane and Lubatkin (1998), Andersson et al. (2005) and Andersson et al. (2001).

\section{Subsidiary-parent firm embeddedness}

Following earlier studies (Andersson, et al., 2005; Andersson, et al., 2001; Forsgren, et al., 2006; Lane \& Lubatkin, 1998), we operationalized subsidiary-parent firm embeddedness in terms of the mutual adaptation of activities and/or practices. Following these contributions, anchored by 1 'not at all' and 7 'to a very great extent', the respondents were asked to estimate 'the extent to which the relationship between the subsidiary and parent company has caused mutual adaptation concerning a) sales and marketing practices, b) distribution practices and c) management practices'.

\section{Autonomy}

The development of measurements of autonomy was based on Ghoshal and Bartlett (1988) and Ghoshal and Nohria (1989). Respondents were asked to indicate the overall influence of 


\section{Z. Najafi-Tavani et al.}

the subsidiary and its parent company in deciding upon the following issues for the subsidiary: the introduction of new services, restructuring the subsidiary organisation involving creation or elimination of departments, and hiring and firing of the subsidiary's top managers. The questions were based on a seven-point scale ranging from 1 'decided by headquarters' to 7 'decided by subsidiary'.

\section{Subsidiary-subsidiary embeddedness}

Similarly to external embeddedness and subsidiary-parent firm embeddedness, and following the contributions of Andersson et al. (2005; 2001) and Lane and Lubatkin (1998), subsidiarysubsidiary embeddedness is assessed by the level of mutual adaptation of activities. Respondents were asked to estimate the extent to which the relations between their company and sister subsidiaries have resulted in mutual adaptation as regards sales and marketing, distribution and management. All questions were operationalized using a seven-point Likert scale (1 'not at all' and 7 'to a very great extent').

To evaluate the validity of constructs, a confirmatory factor analysis was conducted using LISREL 8.8. Results show that there is no problem with regard to the convergent validity of any of the measures, since, as seen in Table 1, all of the loadings are above 0.7 (except one item of knowledge development and external embeddedness) and the average variance extracted (AVEs) and construct reliabilities (CRs) are all above the required levels of 0.5 and 0.7, respectively. For discriminant validity, all AVEs should be larger than the corresponding squared inter-construct correlation estimates (SIC). According to Table 2, this is the case; thus, discriminant validity is not a problem in this study. The overall chi-square is significant $\left(\chi^{2}=194.88(\mathrm{df}=94) ; \mathrm{p}\right.$-value=0.00), which might be due to statistics sensitivity to the sample size (Bagozzi \& Yi, 1988). Overall, the goodness-of-fit statistics meet all the requirements $(\mathrm{SRMR}=0.055, \mathrm{CFI}=0.94, \mathrm{NNFI}=0.93, \mathrm{IFI}=0.95, \mathrm{RMSEA}=0.077$, ratio of chi-square to 
degrees of freedom $=2.07$ (less than 3 )) to demonstrate the validity of the complete model (Browne \& Cudeck, 1993).

Insert Tables $1 \& 2$ around here

\section{Results}

Hypotheses are tested by way of structural equation modelling, using LISREL 8.8. Table 3 presents the results. External embeddedness emerges as the strongest determinant of knowledge development $(\mathrm{t}$-value $=4.91)$. This means that the more embedded a subsidiary is locally, the more capable it is of developing new knowledge. Therefore, Hypothesis 1 is confirmed.

The results also yield strong support for the association between subsidiary-parent firm embeddedness and knowledge development (Hypothesis 2). Although this relationship is not as influential as that of external embeddedness, our findings show that subsidiary-parent firm embeddedness significantly increases the extent of a subsidiary's knowledge development (tvalue=2.15).

Hypothesis 3 involves the relationship between autonomy and knowledge development. The t-value is of 2.79 , which shows that autonomy significantly and positively influences the extent of knowledge development. Hypothesis 3 is therefore confirmed.

Finally, while the results indicate that subsidiary-subsidiary embeddedness has a positive impact on knowledge development, this relationship is not significant ( $\mathrm{t}-\mathrm{value}=0.27)$. As a result, Hypothesis 4 is rejected.

Subsidiary age and size were included as control variables. We used the natural logarithm of number of employees as an indicator of size and the natural logarithm of year of establishment as an indicator of age. Whilst there are variations in size and age, the results indicate that these do not significantly impact upon the extent of knowledge development, 
with no significant changes in the results of the hypothesis testing. Table 4 illustrates the changes after the introduction of control variables.

\section{Insert Tables 3 and 4 around here}

\section{Discussion}

The main aim of this research is to shed light on the issue of knowledge development within subsidiaries in the KIBS sector. Drawing on a sample of 184 subsidiaries located in the UK, we suggest that a subsidiary's relations with its parent firm and local environment are the main facilitators of knowledge development in KIBS companies.

According to our results, there exists a positive and significant relationship between the extent of a subsidiary's knowledge development and its external embeddedness. To develop new knowledge, KIBS firms should have access to 'specialized knowledge' (Koch \& Strotmann, 2008). According to the literature on the service industry, and in particular the KIBS sector, local actors are the main source of specialized knowledge (den Hertog, 2000). Embedded relations serve as knowledge-gathering devices that boost a firm's ability to develop knowledge. Previous contributions also support this finding (i.e. Almeida \& Phene, 2004; Andersson, et al., 2005; Birkinshaw, 1996; Håkanson \& Nobel, 2001); Andersson et al. and Håkanson and Nobel, for instance, demonstrate that the extent of embeddedness with local actors has a positive influence on subsidiary innovativeness. Birkinshaw (1996) finds that local actors constitute one of the main sources of competitive advantage for subsidiaries.

Overall, our results confirm that, in the case of the KIBS sector, developing and maintaining embedded relations with the local environment is one of the main prerequisites for knowledge development.

Furthermore, within the KIBS sector, subsidiaries that maintain high levels of internal embeddedness with their parents can considerably augment their ability to develop 
knowledge. This confirms results from studies focusing on innovation, which showed that access to various sources of knowledge (e.g. knowledge of sister subsidiaries) facilitates the creation of new ideas (Frost, 2001) and can even be considered as the main source of knowledge development (Buckley \& Carter, 1996). Our study demonstrates that, similarly to firms in the manufacturing sector (Gupta \& Govindarajan, 1991), local actors and the parent firm can serve as main sources of knowledge for subsidiaries in the KIBS sector.

The extant literature on knowledge development highlights the importance of autonomy (Frost, et al., 2002; Gupta \& Govindarajan, 1991). A lack of autonomy impacts negatively on knowledge development by decreasing the openness of the firm to new ideas (Miller, et al., 1988). Cantwell and Piscitello (1999) find that a low level of autonomy prevents a subsidiary from making decisions independently and thus prevents knowledge development. Within the KIBS sector, to be capable of developing new knowledge, firms should develop and maintain embedded relationships with local actors. However, a low level of autonomy may prevent such firms from building close or strong ties with the local environment and may therefore hinder learning patterns (Damanpour, 1991; Miller, et al., 1988). In line with earlier studies (Ghoshal \& Bartlett, 1988; Grevesen \& Damanpour, 2007), our study clearly confirms that in the KIBS sector, a high level of autonomy is crucial for knowledge development.

Contrary to expectations, the results do not support a relationship between subsidiarysubsidiary embeddedness and knowledge development. There could be several reasons for this. Firstly, as mentioned earlier, in order to be successful, KIBS firms should be fully integrated into their local environment. However, a high level of external embeddedness is usually associated with highly context-specific relations (Andersson, Forsgren, \& Holm, 2002). This means that the subsidiary may allocate more resources and time to activities that are specific to external relations, thereby paying less attention to other internal sources of knowledge. Secondly, because knowledge in KIBS subsidiaries is usually embedded in 


\section{Z. Najafi-Tavani et al.}

employees' activities and skills, it is highly tacit in nature. Tacit knowledge can only be effectively transferred through rich transmission mechanisms (i.e. face-to-face interactions), and both sender and receiver have to be willing to allocate time and resources to such knowledge transfer activities. Thirdly, KIBS subsidiaries may be reluctant to share knowledge with sister companies for fear of losing monopoly power, especially if reliable knowledge protection mechanisms (such as patents) are lacking. Finally, the focal subsidiary may ignore competencies residing in its sister subsidiaries, due to the 'not invented here' syndrome (Katz \& Allan, 1982), or just because of difficulties in understanding and recognizing the value and potential of tacit knowledge.

\section{KIBS knowledge development and dual embeddedness}

In line with prior studies in the manufacturing sector (e.g. Birkinshaw, et al., 1998; Ghoshal \& Bartlett, 1988; Grevesen \& Damanpour, 2007), we found that subsidiary-parent firm embeddedness and external embeddedness are the main facilitators of knowledge development in KIBS subsidiaries. However, while relations with the parent firm can serve as a source of knowledge, our results suggest that they are not as influential as the subsidiary's relations with business partners in the local environment. Our results confirm Yamin (1999), who suggests that, to develop knowledge, manufacturing companies rely more on their parent firms, but service companies rely more on their local environment. The greater demand for adaptation and localization may explain the importance of external embeddedness on knowledge development activities of KIBS firms. In particular, customers of KIBS firms are considered as 'co-producer' and 'co-creator' of new knowledge (den Hertog, 2000). According to Bettencourt et al. (2002), KIBS firms' activities are highly customized and their success depends largely on the effectiveness and efficiency of interaction and co-operation with local actors, and in particular with customers. 


\section{Implications and limitations}

Our results demonstrate that a subsidiary's competitive advantage depends heavily on its ability to develop and maintain business relationships. It is through these relations that the subsidiary can benefit from diverse sources of knowledge existing in its internal and external networks. The results entail the following implications:

As expected, the local environment is one of the main sources of competitive advantage for KIBS firms. Given that KIBS companies are involved in activities that are highly customized and complicated, having close relations with local actors is essential for the success of firms in this sector. In fact, through close relations, the subsidiary co-creates or co-produces knowledge with local actors. Therefore, subsidiaries should maintain and improve their relations with customers, suppliers, universities and competitors, in order to be capable of developing new knowledge.

In addition to local environment, this research shows that the quality of the relationship between a subsidiary and its parent significantly influences knowledge development. This indicates that the success or even survival of KIBS subsidiaries still depends heavily on receiving intangible resources from parent firms. In fact, these relationships serve as knowledge-gathering devices which can create trust and avoid conflict.

Although this study contributes to the extant literature in various ways, as with any contribution, it suffers from some limitations, which should be taken into account when interpreting the results. First, our research aimed to understand how a subsidiary's network of relations influences its knowledge development activities. Consequently, we focused only on the association between knowledge development and (a) external embeddedness, (b) subsidiary-parent firm embeddedness, (c) autonomy, and (d) subsidiary-subsidiary embeddedness. However, prior studies have identified other factors that also affect subsidiaries' knowledge development, such as, among others, the technological richness of 


\section{Z. Najafi-Tavani et al.}

the MNCs, absorptive capacity, a subsidiary's strategic role, or formalization (Almeida \& Phene, 2004; Ghoshal \& Bartlett, 1988). Future studies could investigate how the aforementioned factors facilitate/inhibit subsidiaries' knowledge development within the KIBS sector. Moreover, with regard to the subsidiary's local environment, further research is required to understand which capabilities a firm may need to absorb and assimilate local knowledge, and to unravel the problems firms face in understanding and dealing with their local environment.

Second, the conceptual framework is tested only within the KIBS sector. Although this research has produced invaluable implications for that sector, it is not clear whether they are generalizable to other industries. Therefore, collecting data from other sectors would provide an opportunity to compare subsidiary knowledge creation for different sectors.

Finally, this research was conducted during a recessionary period, during which many companies were struggling to survive. Such situations may influence the knowledge-sharing activities of firms or even managers' perceptions of such activities. For instance, the lack of a significant influence of subsidiary-subsidiary embeddedness on knowledge development may be due either to subsidiaries preferring to allocate their resources to survival rather than to transferring their knowledge to other parts of the corporation; or that the situation had a negative impact on the perceptions of managers about the importance of resources residing in sister subsidiaries. Therefore, it could be concluded that the timing of the research may have influenced the results. 


\section{References}

Almeida, P., \& Phene, A. (2004). Subsidiaries and Knowledge Creation: The Influence of the MNC and Host Country on Innovation. Strategic Management Journal, 25(8-9), 847-864.

Andersson, U., Björkman, I., \& Forsgren, M. (2005). Managing Subsidiary Knowledge Creation: The Effect of Control Mechanisms on Subsidiary Local Embeddedness. International Business Review, 14(5), 521-538.

Andersson, U., Forsgren, M., \& Holm, U. (2001). Subsidiary Embeddedness and Competence Development in MNCs A Multi-Level Analysis. Organization Studies, 22(6), 1013-1034. doi: 10.1177/0170840601226005

Andersson, U., Forsgren, M., \& Holm, U. (2002). The Strategic Impact of External Networks: Subsidiary Performance and Competence Development in the Multinational Corporation. Strategic Management Journal, 23(11), 979-996.

Bagozzi, R., \& Yi, Y. (1988). On the Evaluation of Structural Equation Models. Journal of the Academy of Marketing Science, 16(1), 74-94. doi: 10.1007/bf02723327

Bettencourt, L. A., Ostrom, A. L., Brown, S. W., \& Roundtree, R. I. (2002). Client Co-Production in Knowledge-Intensive Business Services. California Management Review, 44(4), 100-128.

Birkinshaw, J. (1996). How Multinational Subsidiary Mandates are Gained and Lost. Journal of International Business Studies, 27(3), 467-495.

Birkinshaw, J., \& Hood, N. (1998). Multinational Subsidiary Evolution: Capability and Charter Change in Foreign-Owned Subsidiary Companies. The Academy of Management Review, 23(4), 773795.

Birkinshaw, J., Hood, N., \& Jonsson, S. (1998). Building Firm-Specific Advantages in Multinational Corporations: The Role of Subsidiary Initiative. Strategic Management Journal, 19(3), 221241.

Bouquet, C., \& Birkinshaw, J. (2008). Weight versus Voice: How Foreign Subsidiaries Gain Attention from Corporate Headquarters. Academy of Management Journal, 51(3), 577-601.

Browne, M. W., \& Cudeck, R. (1993). Alternative Ways of Assessing Model Fit In K. A. Bollen, \& J. S. Long (Eds.), Testing Structural Equation Models (pp. 136-162). Newbury Park, CA: Sage.

Buckley, P. J., \& Carter, M. J. (1996). The Economics of Business Process Design: Motivation, Information and Coordination within the Firm. International Journal of the Economics of Business, 3(1), 5-25.

Buckley, P. J., Pass, C. L., \& Prescott, K. (1992). The Internationalization of Service Firms: A Comparison with the Manufacturing Sector. Scandinavian International Business Review, 1(1), 39-56.

Cantwell, J., \& Piscitello, L. (1999). The Emergence of Corporate International Networks for the Accumulation of Dispersed Technological Competences. Management International Review, 39(1), 123-147.

Czarnitzki, D., \& Spielkamp, A. (2003). Business Services in Germany: Bridges for Innovation. The Service Industries Journal, 23(2), 1-30.

Damanpour, F. (1991). Organizational Innovation: A Meta-Analysis of Effects of Determinants and Moderators. The Academy of Management Journal, 34(3), 555-590.

den Hertog, P. (2000). Knowledge-Intensive Business Services as Co-Producers of Innovation. International Journal of Innovation Management, 4(4), 491-528.

Dillman, D. A. (2000). Mail and Internet surveys: The Tailored Design Method (2nd edition) New York: John Wiley \& Sons Inc.

Doloreux, D., Amara, N., \& Landry, R. (2008). Mapping Regional and Sectoral Characteristics of Knowledge-Intensive Business Services: Evidence from the Province of Quebec (Canada). Growth and Change, 39(3), 464-496.

Egelhoff, W. (1988). Organizing the Multinational. An information Processing Perspective. New York: Ballinger. 


\section{Z. Najafi-Tavani et al.}

Forsgren, M., Holm, U., \& Johanson, J. W. (2006). Managing the Embedded Multinational: A Business Network View. Cheltenham: Edward Elgar Publishing.

Frost, T. S. (1990). The Geographic Sources of Innovation in Multinational Enterprise: U.S. Subsidiaries and Host Country Spillovers. Doctoral dissertation, Sloan School of Management, MIT, Massachusetts.

Frost, T. S. (2001). The Geographic Sources of Foreign Subsidiaries' Innovations. Strategic Management Journal, 22(2), 101-123.

Frost, T. S., Birkinshaw, J. M., \& Ensign, P. C. (2002). Centers of Excellence in Multinational Corporations. Strategic Management Journal, 23(11), 997-1018.

Gerbing, D. W., \& Anderson, J. C. (1988). An Updated Paradigm for Scale Development Incorporating Uni. JMR, Journal of Marketing Research, 25(2), 186-192.

Ghoshal, S., \& Bartlett, C. A. (1988). Creation, Adoption, And Diffusion Of Innovations By Subsidiaries Of Multinational Corporations. Journal of International Business Studies, 19(3), 365-388.

Ghoshal, S., \& Nohria, N. (1989). Internal Differentiation within Multinational Corporations. Strategic Management Journal, 10, 323-337.

Grevesen, C. W., \& Damanpour, F. (2007). Performance Implications of Organisational Structure and Knowledge Sharing in Multinational R\&D Networks. International Journal of Technology Management, 38(1/2), 113-136.

Grosse, R. (1996). International Technology Transfer in Services. Journal of International Business Studies, 27(4), 781-800.

Gupta, A. K., \& Govindarajan, V. (1991). Knowledge Flows and the Structure of Control within Multinational Corporations. Academy of Management Review, 16(4), 768-792.

Håkanson, L., \& Nobel, R. (2001). Organizational Characteristics and Reverse Technology Transfer. Management International Review (MIR), 41(4), 395-420.

Hansen, M. T. (2002). Knowledge Networks: Explaining Effective Knowledge Sharing in Multiunit Companies. Organization Science, 13(3), 232-248.

Hoang, H., \& Rothaermel, F. T. (2010). Leveraging Internal and External Experience: Exploration, Exploitation, and R\&D Project Performance. Strategic Management Journal, 9999(9999), n/a.

Johannisson, B. (1998). Personal Networks in Emerging Knowledge-based Firms: Spatial and Functional Patterns. Entrepreneurship \& Regional Development, 10(4), 297-312.

Johanson, J., \& Vahlne, J.-E. (2009). The Uppsala Internationalization Process Model Revisited: From Liability of Foreignness to Liability of Outsidership. Journal of International Business Studies, 40(9), 1411-1431. doi: citeulike-article-id:6212574

Katz, R., \& Allan, T. J. (1982). Investigating the Not-Invented-Here (NIH) Syndrome: A Look at the Performance, Tenure, and Communication Patterns of 50 R\&D Project Groups. R\&D Management, 12(1), 7-20.

Koch, A., \& Strotmann, H. (2008). Absorptive Capacity and Innovation in the Knowledge Intensive Business Service Sectors. Economics of Innovation and New Technology, 17(6), 511-531. doi: $10.1080 / 10438590701222987$

Kogut, B., \& Zander, U. (1992). Knowledge of the Firm, Combinative Capabilities, and the Replication of Technology. Organization Science, 3(3), 383-397.

Konrad, A. M., \& Linnehan, F. (1995). Formalized HRM Structures: Coordinating Equal Employment Opportunity or Concealing Organizational Practices? The Academy of Management Journal, 38(3), 787-820.

Kotabe, M., Martin, X., \& Domoto, H. (2003). Gaining from Vertical Partnerships: Knowledge Transfer, Relationship Duration, and Supplier Performance Improvement in the U.S. and Japanese Automotive Industries. Strategic Management Journal, 24(4), 293-316.

Lane, P. J., \& Lubatkin, M. (1998). Relative Absorptive Capacity and Interorganizational Learning. Strategic Management Journal, 19(5), 461-477.

Miles, I., Kastrinos, N., \& Flanagan, K. (1995). Knowledge-Intensive Business Services: Users, Carriers and Sources of Innovation PREST working paper (pp. 1-117). Manchester. 
Miller, D., Droge, C., \& Toulouse, J.-M. (1988). Strategic Process and Content as Mediators between Organizational Context and Structure. The Academy of Management Journal, 31(3), 544-569.

Mudambi, R., Mudambi, S. M., \& Navarra, P. (2007). Global Innovation in MNCs: The Effects of Subsidiary Self-Determination and Teamwork. Journal of Product Innovation Management, 24(5), 442-455.

Muller, E. (2001). Innovation Interactions Between Knowledge-Intensive Business Services and Smalland Mediumsized Enterprises - Analysis in Terms of Evolution, Knowledge and Territories. Physica: Heidelberg.

Muller, E., \& Doloreux, D. (2009). What we should Know about Knowledge-Intensive Business Services. Technology in Society, 31(1), 64-72.

Muller, E., \& Zenker, A. (2001). Business Services as Actors of Knowledge Transformation: The Role of KIBS in Regional and National Innovation Systems. Research Policy, 30(9), 1501-1516.

Nobel, R., \& Birkinshaw, J. (1998). Innovation in Multinational Corporations: Control and Communication Patterns in International R\&D Operations. Strategic Management Journal, 19(5), 479-496.

Podsakoff, P. M., \& Organ, D. W. (1986). Self-reports in Organizational Research: Problems and Prospects. Journal of Management, 12, 69-82.

Porter, M. E. (1990). The Competitive Advantage of Nations. New York: Free Press.

Rogers, E., \& Larsen, J. (1984). Silicon Valley Fever. New York: Basic Books.

Roth, M. S., Jayachandran, S., Dakhli, M., \& Colton, D. A. (2009). Subsidiary Use of Foreign Marketing Knowledge. Journal of International Marketing, 17(1), 1-29.

Schreiner, M., Kale, P., \& Corsten, D. (2009). What Really is Alliance Management Capability and How does it Impact Alliance Outcomes and Success? Strategic Management Journal, 30(13), 13951419.

Simmie, J., \& Strambach, S. (2006). The Contribution of KIBS to Innovation in Cities: An Evolutionary and Institutional Perspective. Journal of Knowledge Management, 10(5), 26-40.

Squire, B., Cousins, D. P., \& Brown, S. (2009). Cooperation and Knowledge Transfer within BuyerSupplier Relationships: The Moderating Properties of Trust, Relationship Duration and Supplier Performance. British Journal of Management, 20(4), 461-477.

Sternberg, R., \& Arndt, O. (2001). The Firm or the Region: What Determines the Innovation Behavior of European Firms? Economic Geography, 77(4), 364-382.

Szulanski, G. (1996). Exploring Internal Stickiness: Impediments to the Transfer of Best Practice within the Firm. Strategic Management Journal, 17, 27-43.

Taggart, J. (1997). Autonomy and Procedural Justice: A Framework for Evaluating Subsidiary Strategy. Journal of International Business Studies, 28(1), 51-76. doi: citeulike-article-id:4079452

Teece, D. J. (1977). Technology Transfer by Multinational Firms: The Resource Cost of International Technology Transfer. Economic Journal, 87, 242-261.

Uzzi, B. (1997). Social Structure and Competition in Interfirm Networks: The Paradox of Embeddedness. Administrative Science Quarterly, 42(1), 35-67.

Williams, C., \& Nones, B. (2009). R\&D Subsidiary Isolation in Knowledge-Intensive Industries: Evidence from Austria. R\&D Management, 39(2), 111-123.

Windrum, P., \& Tomlinson, M. (1999). Knowledge-Intensive Services and International Competitiveness: A Four Country Comparison. Technology Analysis \& Strategic Management, 11(3), $391-408$.

Yamin, M. (1999). An Evolutionary Analysis of Subsidiary Innovation and 'Reverse' Transfer in Multinational Companies In Burton, F./Chapman, M./Cross, A. (eds.), International Business Organization: Subsidiary Management, Entry Strategies and Emerging Markets (pp. 67-82). Basingstoke: MacMillan Press.

Zander, I., \& Sölvell, Ö. (2000). Cross Border Innovation in the Multinational Corporation: A Research Agenda. International Studies of Organization and Management, 30(2), 44-67. 
Table 1: The constructs and the ir indicators

\begin{tabular}{|c|c|c|c|c|c|}
\hline \multirow{2}{*}{$\begin{array}{l}\text { Indic ators } \\
\text { Knowledge Develop ment, adapted from Ande rsson et al }\end{array}$} & Mean & SD & $A$ & t-value & $\mathrm{R}^{2}$-value \\
\hline & $(2005)$ & $=0.836$ & $\mathrm{AVE}=$ & $1.568, \mathrm{C}$ & $=0.840$ \\
\hline \multirow{4}{*}{$\begin{array}{l}\text { Deve lo pment of sales and marketing know-how } \\
\text { Deve lo pment of distribution know-how } \\
\text { Deve lo pment of service production strategy } \\
\text { know-how } \\
\text { Deve lo pruent of manage me nt syste ms and } \\
\text { practices know-how }\end{array}$} & 4.56 & 1.60 & 0.76 & 11.25 & 0.58 \\
\hline & 4.34 & 1.78 & 0.74 & 10.87 & 0.55 \\
\hline & 5.02 & 1.53 & 0.82 & 12.62 & 0.67 \\
\hline & 4.32 & 1.79 & 0.69 & 9.97 & 0.48 \\
\hline \multicolumn{6}{|c|}{$\begin{array}{l}\text { External Embeddedness, adapted from Lane and Lubatkin (1998), Andersson et al. (2005), and } \\
\text { Andersson et al. (2001), } \alpha=0.754, \mathrm{AVE}=0.516, \mathrm{CR}=0.761\end{array}$} \\
\hline \multicolumn{6}{|c|}{$\begin{array}{l}\text { Adaptation of the following practices from suppliers, } \\
\text { customers, unive rsities, and competitors: }\end{array}$} \\
\hline$>$ Adaptation in sales and marketing practices & 4.81 & 1.49 & 0.66 & 8.87 & 0.43 \\
\hline - Adaptatior & 4.57 & 1.47 & 0.70 & 9.46 & 0.49 \\
\hline * Adaptation in management sustem and practices & 4.55 & 1.46 & 0.79 & 10.89 & 0.62 \\
\hline \multicolumn{6}{|c|}{$\begin{array}{l}\text { Subsidiary-p arent firm Embeddedness, adapted from Lane and Lubatkin (1998), Andersson et al. } \\
\text { (2005), and Ande rsson et al. (2001), } \alpha=0.888, \mathrm{AVE}=0.729, \mathrm{CR}=0.890\end{array}$} \\
\hline \multicolumn{6}{|c|}{$\begin{array}{l}\text { Adaptation of the following practices from parent } \\
\text { company. }\end{array}$} \\
\hline 7 Adaptation in sales and marketing practices & 4.54 & 1.65 & 0.85 & 13.59 & 0.72 \\
\hline Adaptation in distribution practices & 4.54 & 1.70 & 0.89 & 14.53 & 0.79 \\
\hline$>$ Adaptation in management practices & 4.73 & 1.58 & 0.82 & 13.11 & 0.67 \\
\hline \multicolumn{6}{|c|}{$\begin{array}{l}\text { Subsidiary-sub sidiary E mbeddedness, adapted from Lane and Lubatkin (1998), Andersson et al. } \\
\text { (2005), and Andersson et al. }(2001), \alpha=0.919, \mathrm{AVE}=0.798, \mathrm{CR}=0.922\end{array}$} \\
\hline \multicolumn{6}{|c|}{\begin{tabular}{l|l|l|l|l|l} 
Adaptation of the following practices from sister & & & & & \\
subsidiaries:
\end{tabular}} \\
\hline$>$ Adaptation in sales and marketing practices & 3.63 & 1.62 & 0.88 & 14.72 & 0.77 \\
\hline Adaptation in distribution practices & 3.68 & 1.62 & 0.88 & 14.64 & 0.77 \\
\hline$>$ Adaptation in management practices & 3.46 & 1.61 & 0.92 & 15.74 & 0.85 \\
\hline \multicolumn{6}{|c|}{$\begin{array}{l}\text { Autonomy, adapted from Ghoshal and Bartlett (1988) and Ghoshal and Nohria }(1989), \alpha=0.836 \text {, } \\
\mathrm{AVE}=0.513, \mathrm{CR}=0.759\end{array}$} \\
\hline \multirow{3}{*}{$\begin{array}{l}\text { Introduc tion of ne we rvices } \\
\text { Restruc turing of the subsidiary organization } \\
\text { involving creation or elimination of de partments } \\
\text { Hiring and firing of the subsidiary's top managers }\end{array}$} & 3.47 & 1.27 & 0.85 & 13.33 & 0.72 \\
\hline & 3.04 & 1.43 & 0.80 & 12.22 & 0.64 \\
\hline & 3.67 & 1.32 & 0.83 & 12.81 & 0.69 \\
\hline
\end{tabular}

Fit $S$ tatistics : $\chi=19488$ (df=94), SRMR: $0.055, \mathrm{CFI}=094, \mathrm{H} \mathrm{HFI}=093, \mathrm{IFI}=0.95$, RMS EA $=0.077$ 
The Service Industries Journal

Table 2: Squared Inter-Construct Correlation Estimates ard related AVEs

\begin{tabular}{|c|c|c|c|c|c|}
\hline & $\begin{array}{l}\text { Knowledge } \\
\text { Development }\end{array}$ & $\begin{array}{c}\text { Extemal } \\
\text { Embeddedress }\end{array}$ & Autorumy & $\begin{array}{l}\text { Subsidiary- } \\
\text { pare nt firm } \\
\text { Embeddedress }\end{array}$ & $\begin{array}{l}\text { Subsidiary- } \\
\text { subsidiary } \\
\text { Embeddedress }\end{array}$ \\
\hline $\begin{array}{l}\text { Krowledge } \\
\text { Development }\end{array}$ & .568 & & & & \\
\hline $\begin{array}{l}\text { Extemal } \\
\text { Exbeddedress }\end{array}$ & .3025 & .516 & & & \\
\hline Autororry & .04 & .0001 & 513 & & \\
\hline $\begin{array}{l}\text { Subsidiary- } \\
\text { parent firm } \\
\text { Embeddedress }\end{array}$ & .1521 & .16 & .0025 & .729 & \\
\hline $\begin{array}{l}\text { Subsidiary- } \\
\text { subsidiary } \\
\text { Errbeddedress }\end{array}$ & .04 & .0324 & .01009 & .1681 & .798 \\
\hline
\end{tabular}

Wote: Bold numbers on the diagonal show the AVE

Table 3: Results of hypotheses testirg

\begin{tabular}{|c|c|c|c|}
\hline Paths & Hypotheses & t-values & Beta coeffir ient \\
\hline $\begin{array}{l}\text { Ex te mal Errbedde dress =s=Krowledge } \\
\text { Developme nt }\end{array}$ & $\mathrm{H} 1$ & 4.91 & 47 \\
\hline $\begin{array}{l}\text { Subsidiary-pare nt firm Embe dde dress }=5 \\
\text { Krowledge Development }\end{array}$ & $\mathrm{H} 2$ & 2.15 & 20 \\
\hline Autonomy $==$ Knowledge Develo prient & $\mathrm{H3}$ & 2.79 & .21 \\
\hline $\begin{array}{l}\text { Subsidiary-subsidiary Ernbeddedness = }= \\
\text { Krowledge Developrent }\end{array}$ & $\mathrm{H} 4$ & 27 & .022 \\
\hline
\end{tabular}

Table 4. Results of hyptheses testing before and after the introduction of control variables

\begin{tabular}{|c|c|c|}
\hline Paths & Model 1 & Model 2 \\
\hline Exte mal Erbeddedress =:=Krowledge Development & 4.91 & 4.94 \\
\hline Subsidiary-parent firm Embedde dre $s=-=$ Knowle dge Deve lo prone nt & 2.15 & 2.03 \\
\hline Auto romy $==$ Krowledge Developrie nt & 2.79 & 2.90 \\
\hline Subsidiary-subsidiary Embeddedress = = Krowledge Development & 27 & .26 \\
\hline Size & - & 97 \\
\hline Age & - & 68 \\
\hline
\end{tabular}

